de caso sobre o assunto, adaptados à realidade brasileira.

Muito deverá ainda ser pesquisado para um melhor conhecimento da forma matricial. Não se tem a pretensão de dar todas as respostas mas, sim, contribuir para que as organizações, hoje operando matricialmente no Brasil, possam fazê-lo de forma mais eficaz, e para que aqueles, que pretendem adotar a Matriz, possam ter subsidios para selecionar, delinear $e$ implantar o tipo de Matriz mais adequado às suas necessidades.

\title{
OBSCUROS HERÓIS DE CAPRICÓRNIO
}

ORLANDO MIRANDA

São Paulo, Editora Global, 1986

Livro que retrata o microcosmo social e político de uma cidade operária ao longo das últimas décadas, apresenta uma interessante e original fusão entre as técnicas de investigação sociológica e a linguagem do romance.

Baseado em entrevistas e histórias de vida, coletadas na minúcia dos detalhes, e documentos de época, não os reproduz descritivamente no texto, mas recria as condiçőes de vida, revive as biografias $e$ as situaçôs relevantes, de tal forma a apresentá-las com o sabor literário de um fino enredo que lentamente se desenvolve.

Desse contexto, o cotidiano, o drama pessoal, o inconseqüente, adquirem relevo, conjugam-se ao político e ao social, gerando uma dinâmica es- pecial a conjugar biografias e história numa ousada tentativa de recuperação global do momento e do lugar estudado.

Entretanto, se o autor busca na linguagem literária a expressão mais abrangente para expor e descrever os conteúdos pesquisados, teria, é certo, problemas para alçar-se ao nivel teórico, e os resolve de forma supreendente, sem abandonar a linguagem escolhida, pelo uso da fantasia metafórica, passando do realismo com que conduz as situaçōes de entrevista, para o fantástico com o qual conclui, cruzando de modo significativo personagens, falas e situações.

Um tema aberto, tese e romance, uma visão altamente provocativa da realidade brasileira. 